Bangladesh J. Zool. 42(1): 45-55, 2014

\title{
SEASONAL PREVALENCE OF ARTHROPODA AND HELMINTH PARASITES IN SHEEP (OVIS ARIES)
}

\author{
Tania Yeasmin, Hamida Khanum* and Rimi Farhana Zaman \\ Parasitology Laboratory, Department of Zoology, University of Dhaka, \\ Dhaka-1000, Bangladesh
}

\begin{abstract}
The present investigation was carried out to determine the prevalence of arthropoda and helminth parasites in sheep at Azimpur, Dhaka during February, 2012 to January, 2013. A Total of 60 hosts were examined and about $71.67 \%$ sheep were found to be infested with arthropod parasites. In sheep two species of arthropod parasites, Linognathus vituli $(61.67 \%)$ and Damalinia caprae $(68.33 \%)$ were identified as ecto-parasites. The prevalence of ectoparasites was higher during summer $(85 \%)$, followed by winter $(75 \%)$ and rainy $(55 \%)$. The higher intensity was also recorded in summer $(325.17 \pm 1.92)$. Lambs were found more susceptible $(85.71 \%)$ than adult $(80.95 \%)$ and young $(56 \%)$ sheep and higher in female $(77.27 \%)$ than in male $(68.42 \%)$. Twelve species of helminth parasites were identified, of them, 3 trematodes, 3 cestodes and 6 nematodes, highest prevalence was shown by Strongyloides $s p(71.67 \%)$ and lowest by Dictyocaulus sp. (3.33\%); found comparatively higher in adults $(85.71 \%)$ than in young $(80 \%)$ and $28 \%$ in lambs. The male sheeps were more susceptible $(81.58 \%)$ to helminth infection than female $(72.73 \%)$. Prevalence of helminthes was found higher in winter $(95 \%)$ season. The value of co-efficient of correlation between the prevalence and intensity of infestation of ectoparasites and helminth parasites in sheep were 0.95 and 0.978 respectively. In both cases these two variables differed significantly $(\mathrm{P}<0.01)$.

Key words: Infestation, sheep, arthropods, helminthes, seasons.
\end{abstract}

\section{INTRODUCTION}

The economy of Bangladesh largely depends on agriculture; livestock and about $80 \%$ people of the country are directly or indirectly depend on agriculture (Bhuyan 1978). With an annual growth rate of over $8 \%$ since 1993, the contribution of the livestock sub-sector to GDP is 3.2\% (DLS 2012). Shortage of livestock products is attributing to the prevalence of diseases. Sheep (Ovis aries), a member of the family Bovidae and sub family Caprinae, is one of the oldest domesticated animal. In tropics sheep are essentially valuable for meat production (Devendra and Coop 1982). Sheep's meat (mutton) might be an additional source of protein as sheep give 5,000 metric tons meat per year in Bangladesh (BBS 2001).

Sheep are infested by many types of parasites in our country (Islam, 1989). Ectoparasite infestation is one of the major veterinary problems affecting livestock industries in many parts of the world. Ectoparasites including lice, ticks, mites etc. play an important role in transmission of certain pathogens and 
known to cause heavy economic loss to livestock industry due to their usual habit of sucking blood, which adversely affects the economic development. Among ectoparasites, ticks have been recognized as a notorious threat due to severe irritation, blood loss, allergy and toxicosis. (Niyonzema and Kiltz 1986). In some cases ticks have been reported to cause lower productivity, mortality and transmit diseases such as theileriosis, babesiosis etc. (Norval et al. 1984).

Sheep are infested with various ectoparasites, among them remarkable prevalence was recorded in case of Damilinia ovis (58.8\%) in Iran (Yakhchali and Hosseine 2006). Most common species of tick spread almost throughout the world was Haemaphysalis bipinosa infesting sheep in the state of Tamil Nadu, India (Latha et al. 2004). Chhabra et al. (1988) recorded $15.9 \%$ sheep infested with ectoparasites among them Haemaphysalis spp. (2.6\%) and Boophilus microplus $(0.8 \%)$ were recorded.

Adesh et al. (2007) identified 2 species of tick (Boophilus microplus, Haemaphysalis bipinosa, biting lice (Damalinia ovis) and sucking lice (Linognathus pedulis) in Himalayan region of Uttarkand, India. Clark and Milne (2003) recorded 30\% sheep infested with Psoroptes ovis in Scottish farm. The lice infestation decreases vigor and lower reproductive capacity of the animals. This type of infestation causes a great economic loss to animal owners through disease and death. Heavy louse infestation may cause pruritus, alopecia, excoriation and self-wounding (Wall and Shearer 1997). In recent years hide damage caused by lice has been increasingly recognized as a significant effect of lice infestations.

Among gastro-intestinal parasites, cestodes found in gut are acquired by eating contaminated food or water found to be largely affecting the ruminants like sheep. This group comprises of the genera Moniezia sp., and Taenia sp., commonly found in domesticated and wild carnivores and harbivores. Trematodes, commonly live in the bile duct of sheep, goat or in the small intestine and may also infect lungs. Trematodes especially include Fasciola spp., Schistosoma sp., aramphistomum sp. etc. Fascioliasis is a well known parasitic disease of various herbivorous animals. A large variety of animals such as cattle, buffalo, sheep, goat etc. show infection rate that varies from $70 \%$ to $90 \%$ in some areas.

The clinical symptoms are weight loss, reduced food intake, diarrhea, and reduced yield. Severe blood and protein loss in intestine due to damage caused by parasites often results in oedema in sub-mandible region. Heamonchus sp. is most pathogenic among blood sucking worms and infection with this parasite often results in severe anemia in the host Schistosoma sp. is the only trematode living in the blood stream of warm blooded hosts. Schistosoma sp. cause disease 
called schistosomiasis or Bilharziasis and it is one of the main helminth diseases, goat or sheep are infected, over 200 million people are infected in at least 75 countries with 500 million people exposed to infection. Schistosoma japonicum, $S$. bovis are mainly found among sheep and goat.

Trichostrongyliasis is a disease occurs in gastro-intestinal tract of cattle, sheep, goat and other herbivorous animals. Filariform larvae of Strongyloides stercoralis. Gnathostoma spinigerrum can generally be found in wet tropical environments. Dicrocoelium is another species which is also found among herbivorous animals. Among roundworms of sheep the commonest are Trichostrongylus sp., hookworms, Ascaris sp., Strongyloides sp. The heavy infection of the worms numbering from 250-400 may lead to loss of about $268 \mathrm{mi}$ blood per day from the host body. FAO (1962) reported that losses from intestinal parasites might be as high as $30 \%$ of the market value. Afazuddin (1985) estimated an annual loss of taka 0.1 million due to parasite infection in Savar, Military farm, Dhaka.

The overall occurrence of ectoparastes and parasites of digestive system and their variation in relation to age and sex of sheep and their seasonal dynamics was not studied adequately. From this point of view, the current study was conducted to study the occurrence of ecto and endoparasites of indigenous sheep with their seasonal dynamics and variation in the occurrence of parasites in relation to age and sex of sheep. The present study might also prove as a roadmap for future researchers.

\section{MATERIAL AND METHODS}

The study took place on sheep at Azimpur area of Dhaka city. The present investigation was carried out during the period of February, 2012 to January, 2013, which covered the winter (January and February), the summer (March to June) and the rainy (July to October) season. Fresh fecal samples collected in the morning and then brought to the parasitology laboratory of Zoology Department, University Of Dhaka to conduct the study.

Hosts: A total of 60 hosts were selected randomly. The minimum age of the sheep was 6 months and the age had been determined according to birth record. To study the relationship between parasite infestation and the age of the host, the sheep were categorized into three groups: lamb ( $\leq 1$ year), young $(>1-2$ years) and adult ( $\geq 2$ years). During collection of fecal samples the age, sex, place, body condition and season of the year were carefully recorded.

Collection and identification of ectoparasites: The ectoparasites were collected carefully from different parts of the body of sheep with forceps. In some cases small hairbrush dipped in ethanol was used for the collection of ectoparasites. 
Morphology or external feature of the arthropod parasites was studied in the laboratory by dissecting $(\times 4)$ microscope and compound $(\times 10)$ microscope. The ectoparasites were preserved in $70 \%$ alcohol in clean well-stoppered glass vials. Vials were labeled properly. Ectoparasites were identified with the help of keys and descriptions given by Soulsby (1982), Roberts (1952) and Wall and Shearer (1997) by making permanent slides by following the procedures described by Cable (1957).

Collection and preservation of fecal sample: Fecal samples of sheep were collected randomly. Fresh samples were collected from 8.00 a.m. to 10.00 a.m. and twice in a month. The feces were picked up in air tied polythene bag to the laboratory of Department of Zoology, University of Dhaka. The polybags were labeled properly. During collection all necessary precautions were taken including wearing apron, hand gloves to avoid contamination. The fecal samples were preserved in $10 \%$ formalin.

Examination of fecal sample: Concentration method: In present study, concentration method was used to study gastrointestinal parasites of sheep (Cheesbrough, 1987). This method provides high concentration of parasites and which is relatively free of contaminating particulate materials. Eggs of various gastrointestinal parasites were identified with the help of compound (10x) microscope. The 40x objective was also used for the confirmation of ova, larvae (non- motile) and cysts.

Calculation of Egg per Gram (EPG): The number of eggs or cysts per gram of feces was calculated by the drop count from the following formula:

$$
\begin{aligned}
& \mathrm{N}=\mathrm{SS} \times \mathrm{P} / \mathrm{TD} \text { Where, } \\
& \mathrm{SS}=\text { Total drops of the sub sample } \\
& \mathrm{P}=\text { Number of parasite (egg or cyst) observed } \\
& \mathrm{TD}=\text { Total number of drops examined }
\end{aligned}
$$

Terminology: All the terminologies used in the current study were according to standard methodology.

\section{RESULTS AND DISCUSSION}

Among hosts examined, $71.67 \%$ sheep were found to be infested with arthropod parasites. Two species of ecto-parasites were detected from the infested hosts, namely: sucking lice, Linognathus vituli (61.67\%) and biting lice, Damalinia caprae (68.33\%) [Table 1]. Linognathus vituli found on Tail, neck, ventral abdominal wall and other parts of the body, whereas, Damalinia caprae collected from Ear, neck, abdominal region and hind part of the body. 
Seasonal prevalence of ectoparasites in sheep: In summer, (85\%), found to be infested with arthropod parasites, during monsoon 55\%, and in winter season $75 \%$ were infested with ectoparasites. The intensity of ectoparasites were (325.18 \pm 1.54$),(293.09 \pm 1.92)$ and $(323.73 \pm 0.39)$ in summer, rainy season and winter respectively. During summer, prevalence of lice was higher in case of Damalinia caprae (60\%), in rainy season higher prevalence were found in case of Linognathus vituli (35\%) and prevalence of Damalinia caprae was higher in winter season (45\%) (Table 1$)$.

Age related prevalence of ectoparasites in sheep: The prevalence of ectoparasites was relatively higher in lambs (85.71\%) followed by adult $(80.95 \%)$ and young (56\%) [Table 2]

Table 1. Prevalence of arthropod parasites and helminths in sheep in different season.

\begin{tabular}{lccccccc}
\hline Season & $\begin{array}{c}\text { No. of } \\
\text { hosts } \\
\text { infested }\end{array}$ & $\begin{array}{c}\text { Prevalence of No. of total } \\
\text { ectoparasites } \\
(\%)\end{array}$ & $\begin{array}{c}\text { Intensity } \\
\text { parasites }\end{array}$ & $\begin{array}{c}\text { Prevalence } \\
(\%) \text { of } \\
\text { helminths }\end{array}$ & $\begin{array}{c}\text { Total of } \\
\text { EPG }\end{array}$ & $\begin{array}{c}\text { Intensity of } \\
\text { helminths }\end{array}$ \\
\hline Summer & 17 & 85 & 5528 & $325.18 \pm 1.54$ & 80 & 4800 & 300 \\
Rainy & 11 & 55 & 3224 & $293.09 \pm 1.92$ & 60 & 2680 & 223.33 \\
Winter & 15 & 75 & 4856 & $323.73 \pm 0.39$ & 95 & 7956 & 418.74 \\
\hline
\end{tabular}

Table 2. Overall prevalence of ectoparasites and helminths in different age groups of sheep.

\begin{tabular}{clcccc}
\hline $\begin{array}{l}\text { No. of } \\
\text { sheep } \\
\text { examined }\end{array}$ & Age of sheep & $\begin{array}{c}\text { No. of sheep } \\
\text { infested with } \\
\text { ectoparasites }\end{array}$ & $\begin{array}{c}\text { Prevalence (\%) } \\
\text { of } \\
\text { ectoparasites }\end{array}$ & $\begin{array}{c}\text { No. of hosts } \\
\text { infected by } \\
\text { helminths }\end{array}$ & $\begin{array}{c}\text { Prevalence } \\
\text { hel of } \\
\text { helminths }\end{array}$ \\
\hline 14 & Lambs ( $\leq 1$ year) & 12 & 85.71 & 9 & 64.28 \\
25 & Young (>1-2 years) & 14 & 56 & 20 & 80 \\
21 & Adult ( $\geq 2$ years) & 17 & 80.95 & 18 & 85.71 \\
\hline
\end{tabular}

Prevalence of ectoparasites in sheep: The female were more susceptible than male to arthropod parasite infestation. $68.42 \%$ male and $77.27 \%$ female were found to be positive for ectoparasite infestation. Prevalence of Linognathus vituli was higher in female $(72.27 \%)$ and prevalence of Damalinia caprae was higher in male (68.24).

Prevalence of gastro-intestinal helminth parasites in sheep: Out of 60 sheep examined, 47 were found infected with different species of endoparasites (78.33\%); 12 species of parasites were identified in sheep; among 47 infected hosts, $48.33 \%$ were found infected with trematodes, $53.33 \%$ with cestodes and $76.67 \%$ were infected with nematodes species (Table 3).

Among trematode parasitic species, highest prevalence was recorded for Fasciola hepatica (43.33\%), followed by Schistosoma bovis (38.33\%) and Dicrocoelium sp. (11.67\%). The standard deviation was highest in case of Schistosoma bovis $( \pm 115.47)$, followed by Fasciola hepatica $( \pm 57.33)$. 
Table 3. Prevalence of gastro-intestinal helminth parasite species in sheep.

\begin{tabular}{llcccc}
\hline Group & Parasite species & $\begin{array}{l}\text { No. of hosts } \\
\text { infected }\end{array}$ & $\begin{array}{c}\text { Range of } \\
\text { EPG }\end{array}$ & Prevalence (\%) & \pm SD \\
\hline Trematode & Fasciola hepatica & 26 & 43.33 & $100-400$ & \pm 57.53 \\
& Dicrocoelium sp. & 7 & 11.67 & $100-100$ & \pm 0.00 \\
& Schistosoma bovis & 23 & 38.33 & $100-500$ & \pm 115.47 \\
Cestode & Taenia saginata & 31 & 51.67 & $100-700$ & \pm 153.96 \\
Cestode & Moniazia expansa & 21 & 35 & $100-400$ & \pm 19.24 \\
Cestode & Echinococcus sp. & 13 & 21.67 & $100-200$ & \pm 134.71 \\
Nematode & Dictyocaulus sp. & 2 & 3.33 & $100-100$ & \pm 68.04 \\
& Bunostomum sp. & 8 & 13.33 & $100-300$ & \pm 13.06 \\
& Chabertia ovina & 12 & 20 & $100-200$ & \pm 27.21 \\
& Trichuris sp. & 28 & 46.67 & $100-500$ & \pm 95.25 \\
& Strongyloides sp. & 43 & 71.67 & $100-400$ & \pm 54.41 \\
& Ostertagia sp. & 5 & 8.33 & $100-100$ & \pm 68.04 \\
\hline
\end{tabular}

In case of cestodes, highest prevalence was observed in Taenia saginata (51.67\%), followed by Moniezia expansa (35\%) and Echinococcus sp. (21.67\%) [Table-3]. Standard deviation was highest in Taenia saginata $( \pm 153.96)$ and lowest in Moniezia expansa ( \pm 19.24$)$.

Age related prevalence of gastro-intestinal parasites in sheep: Prevalence of helminth parasites were found higher $(85.71 \%)$ in case of adult hosts ( $\geq 2$ years), followed by young $(80 \%)$ which were aged $\geq 2$ years and then in lamb $(64.28 \%)$, aged $\geq 1-2$ years. Adults were more susceptible to gastro-intestinal helminth infection (85.71\%) (Table 2).

Prevalence of gastro-intestinal parasites in male and female sheep: It was detected that prevalence of helminth was higher in case of male sheep (81.58\%) than female $(72.73 \%)$. In case of male, prevalence of Strongyloides sp. was highest (65.79\%), followed by Taenia saginata (44.74\%), Trichuris sp. (42.11\%), Fasciola hepatica (39.41\%) and lowest prevalence was shown by Dictyocaulus sp. $(2.63 \%)$. In case of female, highest prevalence was shown also by Strongyloides sp. (81.82\%) followed by Dictyocaulus sp. (4.55\%) (Table 4).

Seasonal prevalence of gastro-intestinal parasites in sheep: Prevalence of helminthes during summer, rainy and winter season were $80 \%, 60 \%$ and $95 \%$ respectively. During summer prevalence of Trematodes, cestodes and nematode parasite were $50 \%, 55 \%$ and $65 \%$ respectively, whereas prevalence of trematode, cestode and nematode was $40 \%, 45 \%$ and $60 \%$ respectively in rainy season and prevalence of trematode, cestode and nematode was $60 \%, 60 \%$ and $90 \%$, respectively in winter season. 

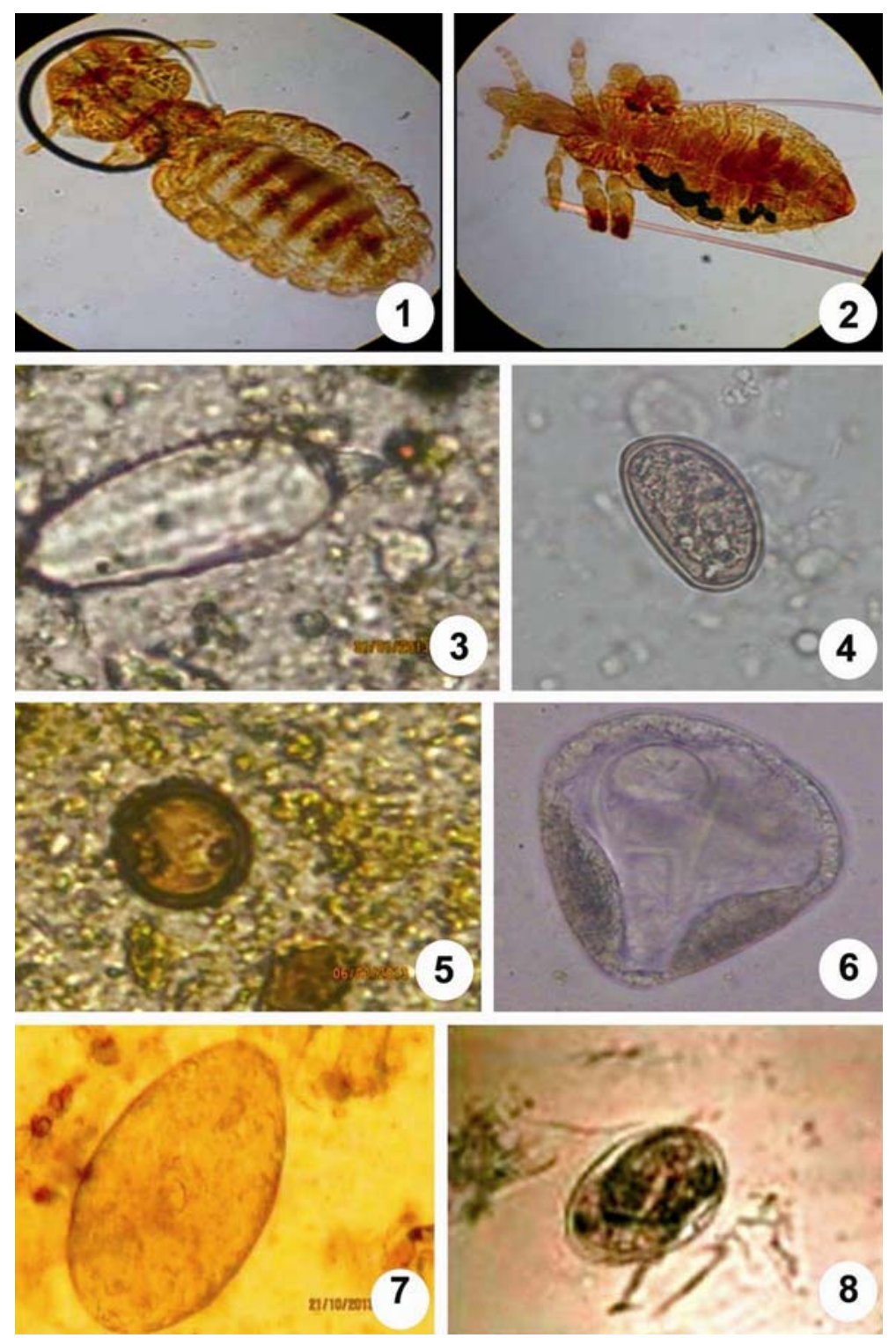

Plates 1-8: Image of egg of helminthes found in sheep. 1. Biting lice (Damalinia caprae). 2. Sucking lice (Linognathus vituli). 3. Schistosoma bovis. 4. Dicrocoelium sp. 5. Taenia saginata. 6. Monizia expansa. 7. Fasciola hepatica. 8. Strongyloides sp.

The prevalence of Strongyloides sp. was highest (71.67\%) in sheep followed by Taenia saginata (51.67\%), Trichuris sp. (46.67\%), and Fasciola hepatica (43.33\%), Chabertia ovina (20\%), Bunostomum sp. (13.33\%), Ostertagia sp. $(8.33 \%)$ and lowest in Dictyocaulus sp. (3.33\%). [Table 3]. 


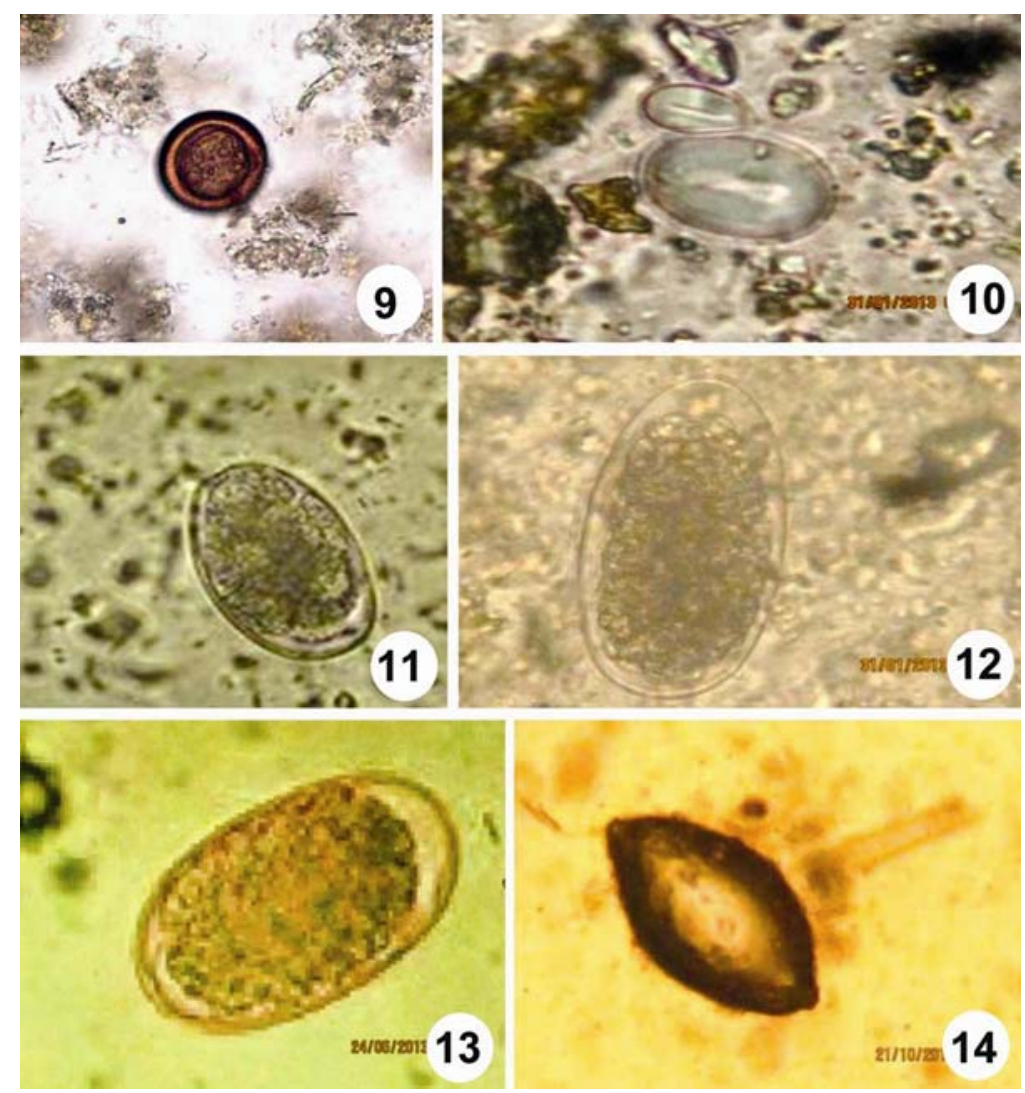

Plates 8-14: 9. Echinococcus sp. 10. Dictyocaulus sp. 11. Bunostomum sp. 12. Chabertia ovina. 13. Ostertagia sp.14. Trichuris sp.

Prevalence of ectoparasites in sheep was recorded $71.67 \%$ and it was found that sheep were infested with two arthropod parasite species, namely Linognathus vituli (61.67\%) and Damalinia caprae (68.33\%). El-seify et al. (1990) recorded $86.7 \%$ infestation with $L$. africanus and $13.3 \%$ infestation with Bovicola caprae in small ruminants of Egypt. Chakrabarty (1994) recorded 13.4\% Psoroptes sp. infestation in small ruminants in India. The differences among the results of present and earlier studies might be due to variation in the geographical area, change in climatic conditions, variation in method of study, selection of sampling procedure and breed of sheep.

In the present observations the prevalence of ectoparasite infestation in sheep depended tremendously on the seasonal fluctuations of the year $(\mathrm{P}<0.01)$. The co-efficient of correlation between the prevalence and intensity of ectoparasites was 0.95, which indicates that the prevalence and intensity of ectoparasite infestation was very strongly and positively correlated and these 
two variables differed significantly $(\mathrm{P}<0.01)$. The overall prevalence of ectoparasites was higher in Brazil, in rainy season (Brito et al., 2005) and tick infestation was high in rainy season in India (Latha et al. 2004). During the present investigation, it was found that age of sheep had a significant impact on arthropod parasite infestation. Lambs were more susceptible (85.71\%) to ectoparasite infestation followed by adult (80.95\%) and young (56\%). The prevalence of Psoroptes sp. was higher in young small ruminants (Chakrabarty, 1994), L. africans infestation was the highest on the kids. It is hard to explain exactly the cause of higher frequency of ectoparasites in kids and older animals. . It may be assumed that some hormonal influences may be associated with this phenomenon. High levels of prolactin and progesterone hormones could make the female more susceptible to any infection (LIoyd 1993). Moreover stress of pregnancy and lactation, which make the female more susceptible to infection.

Jugessur et al. (1998) reported 35.3\% infected small ruminants. Yadav and Tandan (1989) reported 52.7\% Haemonchus sp., 41.7\% Bunostomum sp. and 3.5\% Trichuris sp. infection in India. Rahman (1969), Qadir (1974), Nooruddin et al. (1987) reported same species of helminthes in sheep. Moniezia sp. was reported by Ndao et al. (1991).

Table 4. Prevalence of helminth parasite species infecting male and female sheep.

\begin{tabular}{lcccc}
\hline Name of parasites & $\begin{array}{c}\text { No. of male } \\
\text { infected }\end{array}$ & $\begin{array}{c}\text { Prevalence } \\
(\%)\end{array}$ & $\begin{array}{c}\text { No. of female } \\
\text { infected }\end{array}$ & $\begin{array}{c}\text { Prevalence } \\
(\%)\end{array}$ \\
\hline Fasciola hepatica & 15 & 39.41 & 11 & 50 \\
Dicrocoelium sp. & 3 & 7.89 & 4 & 18.18 \\
Schistosoma bovis & 13 & 34.21 & 10 & 45.46 \\
Taenia saginata & 17 & 44.74 & 14 & 63.64 \\
Moniezia expansa & 9 & 23.68 & 12 & 54.55 \\
Echinococcus sp. & 5 & 13.15 & 8 & 36.37 \\
Dictyocaulus sp. & 1 & 2.63 & 1 & 4.55 \\
Bunostomum sp. & 5 & 13.15 & 3 & 13.64 \\
Chabertia ovina & 7 & 18.42 & 5 & 22.73 \\
Trichuris sp. & 16 & 42.11 & 12 & 54.55 \\
Strongyloides sp. & 25 & 65.79 & 18 & 81.82 \\
Ostertagia sp. & 2 & 5.26 & 3 & 13.64 \\
\hline
\end{tabular}

Impact of seasonal variation was apparent $(\mathrm{P}<0.01)$ in different hosts. The value of co-efficient of correlation between the prevalence and intensity of parasites was 0.978 which indicates that the prevalence and intensity of helminth parasite infestation was very strongly positively correlated, so the two variables differed significantly $(\mathrm{P}<0.01)$. Similar findings were reported by Islam (1989) and he recorded peak occurrence of Trichuris $s p$ in winter. In contrast Shahadat (2003) found higher prevalence during rainy season (75.53\%). 
Shahadat et al. (2003) in Bangladesh reported younger $(68.6 \%)$ sheep were more susceptible than adults $(6 \%)$ in Strongyles infection. Uddin (2006) in Bangladesh reported in Paramphistomum sp. infection higher prevalence observed in adult animals (89.58\%) followed by young animals $(78.57 \%)$. Mollah et al. (1970) found no significant differences in the percentage of infestation between young and adult animals.

Rearing and raising sheep in our country is a way to get economic support for the people especially living in rural areas. The parasitic disease of sheep may cause profound economic loss due to reduced growth, damaged skin, hide and wool, reduced milk production, morbidity, mortality of lamb etc.

\section{LITERATURE CITED}

AFAZUDDIN, M. 1985. General incidence and therapeutic measures of parasitic disease in cattle of Savar Military Dairy Farm. M.Sc. Thesis, Department of Medicine, Bangladesh Agricultural University, Mymensingh. pp.148.

ADESH, K., TRIVED, M. C. and ASHOK, K. 2007. Site preference of Phthiraptera infesting sheep, Department of Zoology, B. L,j Govt. Degree college, Purola (Uttarkashi), Flora and Fauna-jhansi. 13(2): 389-394.

BHUYAN, M. A. 1970. A survey of helminthes parasitizing the lives of Domesticated Ruminants in East Pakistan. M. S. Thesis-12. Department of Parasitology, Bangladesh Agricultural University, Mymensingh. pp: 150.

BRITO, D.R.B., SANTOS, A.C.G. and GUERRA, R.M.S.N.C. 2005. Ectoparasites in goat and sheep herds from the Alto Mearim and Grajau microregion, State of Maranhao. Revista Brasileria de Parasitologia Veterinaria. 14: 59-63.

CABLE, R.M. 1957. An Illustrated Laboratory Manual of Parasitology, 4th edition, Burgress Publishing Co., Minneapolis,Minnesota. U.S.A. p. 111-131.

CHAKRABARTY, D. 1994. Blood biochemical profiles in Fasciola, Haemonchus and Dictyoculus species infection in goats- a comparative study. Indian Veterinry Journal. 71: 286-288.

CHEESBROUGH, M. 1987. Medical Laboratory Manual For Tropical Countries, 2nd edn. Tropical Health Technology, London, Boston, Butterworths. 13: 3-5.

CHHABRA, M.B., GUPTA, S.K. and RUPRAH, N.S. 1988. Ixodid ticks on goats and sheep, In Haryana. Journal of Veterinary Parasitology. 2: 125-128.

CLARK, A.C. and MILNE, R.B. 2003. Ectoparasite awareness in sheep, SAC Veterinary Science division, Disease Surveillance centre, Janetstown, Thurso, Caithness KW14 7XF, UK. Veterinary record. 152(9): 271-272.

DLS, 2012. Expansions and Activities. Department of Livestock services, Government of the people's Republic of Bangladesh. Annual Report.

DEVENDRA, C. and COOP, I.E., 1982. Sheep and Goat Production. World Animal Science, $\mathrm{C}_{1}$. Elsvier Scientific Publishing Company, Armsterdam- Oxford,New York.

EL-SEIFI, M.A., ZAKIA, G.A., AGGOUR, M.G. and SEIFY-MA-EI. 1990. Some studies on lice infesting goats in Beni-Suef, Middle Egypt. Assiut Veterinary Medical Journal. 23(45): 64-74.

FAO/WHO/OIE 1962. The economic losses caused by animal diseases. Animal Health Year Book, 284-313. 
ISLAM, M.K. 1989. Studies on some epidemiological and pathological aspects of Trichuris spp. infection in Black Bengal goats in Mymensingh, Bangladesh. Thesis. M. Sc. (Vet. Science) in Parasitology, Bangladesh Agricultural University, Mymensingh.

ISLAM M.K., ALIM, M.A., TSUJI, N. and MONDAL, M.M.H. 2006. An investigation into the distribution, host preference and population density of Ixodid ticks affecting domestic animals in Bangladesh. Tropical Animal Health and Production. 38:485-490.

JUGESSUR, V. S., RAMJEE, R. and RAMNAUTH, R.K. 1998.The effectiveness of some widely used anthelmintic drugs on endoparasitic nematodes of village goats. Food and Agricultural Research Council, Reduit Mauritius. pp: 32-38.

LATHA, B. R., AIYASAMI, S. S., PATTABIRAMAN, G., SIVARAMAN, T. and G. RAJAVELU. 2004. Seasonal activity of ticks on small ruminants in Tamil Nadu State,India. Tropical Animal Health and Production. 36 : 123-133.

LIOYD, S., 1983. Effect of Pregnancy and lactation up on infection. Veterinary Immunology Immunopathology. 4: 153-176.

MOLLAH, M.M.R., ISLAM, A.W.M.S. and ISLAM, M.K., 1996. Epidemiology of abomosal helminthes in Black Bengal goats in Bangladesh. Indian Journal of Veterinary Medicine. 16: 29-31.

NDAO, M., BELOT, J., ZINSSTAG, J. and PFISTER, K. 1991. Epidemiology of gastro-intestinal helminthiasis in small ruminants in the tree-crooping pasture zone in Senegal. Veterinary Research. 26: 132-139.

NIYONZEMA A. and KILTZ, H.H. 1986. Control of ticks and tick- borne diseases in Burundi. Australian Centre for International Agricultural Research. 17:16-17.

NORVAL, R.A.I., FIVAZ, B.H., LAWRENCE, J.A. and BROWN, A. F. 1984. Epidemiology of tick-borne diseases of cattle in Zimbabwe, Tropical Animal Health and Production. 16: 63-70.

NOORUDDIN, M., BAKI, A. and DAS, J.G. 1987. Clinico-pathological studies of an outbreak of Trichuris in cow calves. Indian Journal of Veterinary Medicine. 7: 116-119.

QADIR, A.N.M.A. 1974. A preliminary survey on the incidence of Trichuris infection in domestic ruminants and pathogenesis related to it.Bangladesh Vet. J. 8: 33-36.

RAHMAN, M. H. 1969. Taxonomic studies of the helminth parasites encountered in the abomosum of ruminants in East Pakistan. M. S. Thesis submitted to

ROBERTS, F. H. S., 1952. Insects Affecting Livestock, $1^{\text {st }}$ edn, Angus and Robertson Ltd. 48, Bloomsbury Street, London, W.C.1. pp: 17-92.

SHAHADAT, M.A., KARIM, M.J., ALAM, M.Z. and MAJUMDER, S. 2003. Seasonal distribution of Haemonchus contortus in Bengal goats. The Bangladesh Veterinarian. 20: 72-76.

SOULSBY, E. J. I., 1982. Helminthes, Arthropod and Protozoa of Domesticated Animals, 7th edition. Bailliere Tindal, London pp:136-346, 365-491 and 763-778.

UDDIN, M. Z., FARZANA, T., BEGUM, N. and MONDOL, M.M.H. 2006. Prevalence of Amphistomes in Black Bengal Goats in Mymensingh district, Bangladesh. Bangl. J. Vet. Med. 4(2): 103-106.

WALL, R. and SHEARER, D. 1997. Veterinary Entomology, 1st edition, Chapman and Hall. London, UK. p. 265 and 290.

YADAV, A.K. and TANDON, V. 1989. Gastro-intestinal nematode infections of goats in a sub-tropical and humid zone of India. Veterinary Parasitology. 33: 135-142.

YAKHCHALI, J.K. and HOSSEINE, M.A. 2006. Prevalence and ectoparasites fauna of sheep and goat flock in Urmia suburb, Iran Veterinary Archive. 76: 431-442, 2006.

(Manuscript received on 8 October, 2013; revised on 30 March, 2014) 